\title{
MOGUĆNOST PRIMJENE ALKALIJSKI AKTIVIRANE ZGURE KAO VEZIVA U MORTU
}

\author{
Goran Ignjatić \\ Sveučilište J. J. Strossmayera u Osijeku, Građevinski fakultet Osijek, student \\ Ivanka Netinger \\ Sveučilište J. J. Strossmayera u Osijeku, Građevinski fakultet Osijek, doc.dr.sc.
}

Sažetak: U radu je istražena mogućnost primjene zgure s deponije u Sisku kao alkalijski aktiviranog veziva u mortu. U tu svrhu izrađeni su uzorci mortova s alkalijski aktiviranom zgurom ili alkalijski aktiviranom mješavinom zgure i silicijske prašine te uzorci morta s portland cementom kao vezivom. Uzorci su njegovani pri sobnoj temperaturi te su im nakon 2 i 28 dana starosti ispitane i uspoređene tlačne i vlačne čvrstoće. S obzirom na činjenicu da se uspjela potaknuti vezivna aktivnost kod inače hidraulički neaktivnog materijala, autori zaključuju da je zguru moguće koristiti kao vezivo. Ipak, prilično niske vrijednosti tlačnih i vlačnih čvrstoća kod mortova sa zgurom u usporedbi s istim vrijednostima kod portland cementnog morta, upućuju na potrebu iznalaženja prikladnijeg načina njege svježeg morta s alkalijski aktiviranom zgurom u sastavu, kako bi mu se osigurale veće čvrstoće.

Ključne riječi: zgura, alkalijski aktivirano vezivo, $\mathrm{NaOH}$, vodeno staklo, mort, zbrinjavanje otpada.

\section{POSSIBILITY OF THE ALCALI ACTIVATED SLAG APPLICATION AS A BINDER IN MORTAR}

\begin{abstract}
The possibility of utilisation of slag from the depot in Sisak as alkali-activated binder in mortar is investigated in the paper. To this purpose, mortar samples made with alkali-activated slag or a mixture of alkaliactivated slag and silica fume and samples of mortar with Portland cement as a binder were prepared. The samples were cured at room temperature, after the age of 2 and 28 days their compressive and tensile strength were tested and compared. Considering the fact that binding activity of usually hydraulically inactive material was achieved, the authors conclude that slag can be used as a binder. However, quite low values of compressive and tensile strength of mortars with slag in comparison with the same properties of portland cement mortar imply a need for finding out of a more convenient regime of fresh mortar curing that would be able to ensure higher values of strength for mortars with alkali-activated slag.
\end{abstract}

Key words: slag, alkali activated binder, $\mathrm{NaOH}$, water glass, mortar, waste management. 


\section{Uvod}

Alkalijski aktivirana veziva pojam su koji podrazumijeva svaki sustav koji koristi alkalijski aktivator koji će započeti reakciju ili niz reakcija kako bi nastao materijal koji posjeduje vezivna svojstva. Istraživanja provedena u sklopu [1] pokazala su da lužine i lužnate soli metala, kao i silikati, aluminati i aluminosilikati, pri dostatnoj koncentraciji alkalija u lužnatoj otopini međusobno reagiraju. Takve se reakcije događaju s mineralima gline, aluminosilikatnim staklima (prirodnog i umjetnog podrijetla) gdje je kalcij odsutan, kao i u sistemima u kojima je kalcij vezivno sredstvo pod djelovanjem prirodnih uvjeta, te se formira vodootporni očvrsli produkt hidroaluminata vrlo sličan prirodnim zeolitima ili liskunima [1]. S obzirom na alkalije upotrijebljenje kao aktivator vezanja, ovakva su veziva nazvana alkalijski aktiviranim cementima. $U$ dosadašnjim istraživanjima [2] alkalijski su aktivirane:

- kaolinske gline

- metakaolin

- leteći pepeo

- visokopećna zgura

- mješavine letećeg pepela i zgure

- mješavine letećeg pepela i metakaolina

- mješavine zgure i metakaolina

- mješavine zgure i crvenog mulja (otpad pri preradi boksita)

- mješavine letećeg pepela

- mješavine letećeg pepela i kaolina.

Materijali za uporabu u alkalijski aktiviranim vezivima moraju sadržavati određenu količinu energetske faze koja je kao staklasta izvorno prisutna kod letećeg pepela ili zgure te su po kemijskom sastavu aluminosilikati [3]. Gline, kao što je ona kaolinska, moraju se transformirati u reaktivni materijal procesom toplinske aktivacije (metakaolin), u kojoj dehidroksilacija minerala gline vodi ka visoko energetskoj, nestabilnoj i gotovo amorfnoj fazi [3].

Prema [4], alkalijski se aktivatori mogu svrstati u šest grupa:

- lužine, ROH

- slabo kisele soli, $\mathrm{R}_{2} \mathrm{CO}_{3}, \mathrm{R}_{2} \mathrm{SO}_{3}, \mathrm{R}_{3} \mathrm{PO}_{4}, \mathrm{RF}$

- silikati, $\mathrm{R}_{2} \mathrm{O} \cdot \mathrm{nSiO}_{3}$

- aluminati, $\mathrm{R}_{2} \mathrm{O} \cdot \mathrm{nAl}_{2} \mathrm{O}_{3}$

- aluminosilikati, $\mathrm{R}_{2} \mathrm{O} \cdot \mathrm{Al}_{2} \mathrm{O}_{3} \cdot(2-6) \mathrm{SiO}_{2}$

- jako kisele soli, $\mathrm{R}_{2} \mathrm{SO}_{4}$

gdje je s R označen alkalijski ion.

Kao najčešće korišteni alkalijski aktivatori navode se mješavine natrijevog ili kalijevog hidroksida ( $\mathrm{NaOH}$ ili $\mathrm{KOH}) \mathrm{s}$ natrijevim ili kalijevim vodenim staklom $\left(\mathrm{nSiO}_{2} \mathrm{Na}_{2} \mathrm{O}\right.$ ili $\left.\mathrm{nSiO}_{2} \mathrm{~K}_{2} \mathrm{O}\right)$ [2]. Reakcija nastala kombinacijom reaktivnog materijala i alkalijskog aktivatora može se opisati u dva koraka: stvaranje reaktivnih vrsta (alkalijska aktivacija) i vezanje [3]. U prvom koraku lužnata porna voda razara čvrstu vezu kako bi proizvela reaktivne vrste silikata i aluminata male molekularne težine. Aktivacija krute tvari je postignuta lužnatim otopinama koje sadrže lužnate hidrokside, lužnate silikate i/lil lužnate karbonate. U drugoj fazi, čisti aluminosilikatni materijali kao što su metakaolin i neke vrste letećeg pepela, vežu se reakcijom kondenzacije što vodi ka formaciji aluminosilikatnih polimera. Ti polimeri formiraju trodimenzionalnu mrežu slične strukture kao u zeolita te su gotovo u potpunosti amorfni. Vezanje alkalijski aktivirane zgure ili drugih materijala koji sadržavaju kalcij može se uz reakciju kondenzacije opisati i reakcijom hidratacije, pri čemu nastaju C-S-H i C-A-H faze, u količinama ovisnim o sadržaju kalcija i lužnatosti otopine.

Kod ove klase cementirajućih materijala alkalijska komponenta nema isključivo ulogu aktivatora, već sudjeluje i u formiranju elemenata sadržanih u produktima hidratacije. Za razliku od portlandskog cementa, gdje se najvažnijom vezivnom komponentom smatra kalcij-silicijev hidrat (C-S-H), vezivna komponenta anorganskih polimernih veziva je rezultat formiranja jedno-, dvo- ili trodimenzionalne amorfne aluminosilikatne mreže molekularnih struktura [5]. Alkalijski aktivirani cementi ili geopolimeri formirani su polimerizacijom pojedinih vrsta aluminata i silikata koji su otpušteni iz njihovih originalnih izvora pri visokoj pH vrijednosti, uz prisustvo lužnatih 
metala. Prema [5], tako nastali proizvodi imaju općenitu formulu $\mathrm{R}_{\mathrm{n}} \cdot\left(\left(-\mathrm{SiO}_{2}\right)_{\mathrm{z}}-\mathrm{AlO}\right)_{n} \cdot \mathrm{wH}_{2} \mathrm{O}$, gdje je $\mathrm{R}$ lužnati metal, z je 1, 2, 3 ili više, a $n$ je stupanj polimerizacije. Molekularna struktura, a time i svojstva anorganskog polimernog veziva, ovise o nekim parametrima koji uključuju kemijski i mineralni sastav sirovine, svojstva njegova otapala, sastav i doziranje alkalijskog aktivatora te uvjete njege mješavine [5].

Ovi se cementi razlikuju od tradicionalnih cemenata po svom visokom udjelu alkalija. Količina alkalija koja je uključena u alkalijski aktiviran cement je određena potrebom za zadovoljenjem stohiometrijskog uvjeta lužine ili lužnatog hidroaluminosilikata kako bi nastali produkti hidratacije [6]. Zbog toga je količina alkalija određena sadržajem amfoternog oksida $\left(\mathrm{Al}_{2} \mathrm{O}_{3}\right)$ sadržanog u čvrstoj fazi. Kada je u pitanju učinak temperature njege, zabilježen je pozitivan učinak povišene temperature njege na prirast čvrstoće u početnom periodu, a negativan učinak u kasnijem periodu očvršćivanja uzoraka [2]. Stoga, učestala njega uzoraka je povišena temperatura u prvih nekoliko sati očvršćivanja.

$\mathrm{U}$ ovom se radu istražuje mogućnost primjene zgure (otpadni proizvod pri proizvodnji metala) kao alkalijski aktiviranog veziva. Naime, na području Republike Hrvatske postoje dvije deponije zgure: deponija blizu Siska i deponija u krugu bivše Željezare Split. Zgura deponirana blizu Siska rasprostranjena je na ukupno 25 ha, a količina odlaganog materijala na tom području procjenjuje se na 1,5 milijuna tona. Zgura na spomenutoj deponiji je mješavina čeličanske zgure (zgure iz proizvodnje čelika) i visokopećne zgure (zgure iz proizvodnje željeza). Navedenoj količini zgure s deponije u Sisku treba pribrojiti i novonastalu količinu od 300000 tona iz trenutne proizvodnje bešavnih cijevi u Željezari Sisak, deponiranu u krugu pogona. Zgura s deponije u Splitu je podrijetlom iz proizvodnje čelika, a deponirana količina se procjenjuje na 30000 tona. Visoka cijena odlaganja ovog otpadnog materijala nameće potrebu za njegovim zbrinjavanjem i iznalaženjem uvijek novih područja primjene. S obzirom na znatno veću količinu zgure iz Siska u odnosu na zguru iz Splita, u ovom smo je radu htjeli pokušati iskoristiti kao vezivo u mortu/betonu.

Za razliku od većine visokopećnih zgura koje pokazuju hidrauličku aktivnost, ova usitnjena mješavina visokopećne i čeličanske zgure nije u stanju biti samostalno vezivo, što je čini idealnim materijalom za alkalijsku aktivaciju. Stoga je u ovom radu upotrijebljena zgura s deponije iz Siska kao alkalijski aktivirano vezivo. Svojstva svježeg (gustoća, konzistencija) i očvrslog (vlačna i tlačna čvrstoća) morta s alkalijski aktiviranom zgurom uspoređena su sa svojstvima morta s portland cementom kao vezivom.

\section{Eksperimentalni dio}

\subsection{Projektiranje sastava mješavina morta}

U eksperimentalnom dijelu rada načinjene su četiri mješavine morta. Mješavine mortova su iste količine veziva u iznosu od $450 \mathrm{~kg} / 1 \mathrm{~m}^{3}$ te je predviđeno da budu plastične konzistencije $(14-20 \mathrm{~cm})$. Kao veziva su korišteni: portland cement, alkalijski aktivirana zgura iz Siska, alkalijski aktivirana mješavina zgure iz Siska i silicijske prašine (omjer 80:20 i omjer 60:40). Prema [7,8,9], silicijska prašina pozitivno utječe na rane čvrstoće morta i betona te je u toj namjeri ovdje i zamijenjen dio zgure u mješavinama silicijskom prašinom.

Finoće mliva pojedinih veziva prikazane su tablicom 1, a njihov kemijski sastav tablicom 2.

\section{Tablica 1 - Finoća mliva veziva}

\begin{tabular}{|c|c|c|}
\hline Vezivo & Finoća mliva $\left(\mathrm{cm}^{2} / \mathrm{g}\right)$ & Gustoća $\left(\mathrm{kg} / \mathrm{dm}^{3}\right)$ \\
\hline CEM I $52,5 \mathrm{~N}$ & $4000-4500$ & 3,01 \\
\hline Zgura Sisak & 5370 & 3,11 \\
\hline Silicijska prašina & 11334 & 2,21 \\
\hline
\end{tabular}




\section{Tablica 2 - Kemijski sastav veziva}

\begin{tabular}{|c|c|c|c|c|c|c|c|c|c|}
\hline Vezivo/Oksidi (\%) & $\mathrm{SiO}_{2}$ & $\mathrm{CaO}$ & $\mathrm{Al}_{2} \mathrm{O}_{3}$ & $\mathrm{Fe}_{2} \mathrm{O}_{3}$ & $\mathrm{MgO}$ & $\mathrm{MnO}$ & $\mathrm{Na}_{2} \mathrm{O}$ & $\mathrm{K}_{2} \mathrm{O}$ & $\begin{array}{c}\text { Gubitak } \\
\text { žarenjem } \\
(\%)\end{array}$ \\
\hline $\begin{array}{c}\text { Cement } \\
\text { CEM I 52,5N }\end{array}$ & 19,74 & 63,35 & 5,33 & 2,25 & 2,72 & 0,18 & 0,30 & 0,84 & 1,34 \\
\hline Zgura Sisak & 17,08 & 24,98 & 5,40 & 25,45 & 10,58 & 8,91 & 0,12 & 0,13 & 4,99 \\
\hline Silicijska prašina & 91,50 & 2,55 & 1,75 & - & 1,00 & - & 0,85 & 0,70 & 1,60 \\
\hline
\end{tabular}

Agregat korišten pri spravljanju svih mješavina je pijesak podrijetlom iz rijeke Drave, gustoće $2,65 \mathrm{~kg} / \mathrm{dm}^{3}$ i granulometrijskog sastava prema slici 1. Prilikom spravljanja mješavina, agregat je bio u zasićenom, površinski suhom stanju.

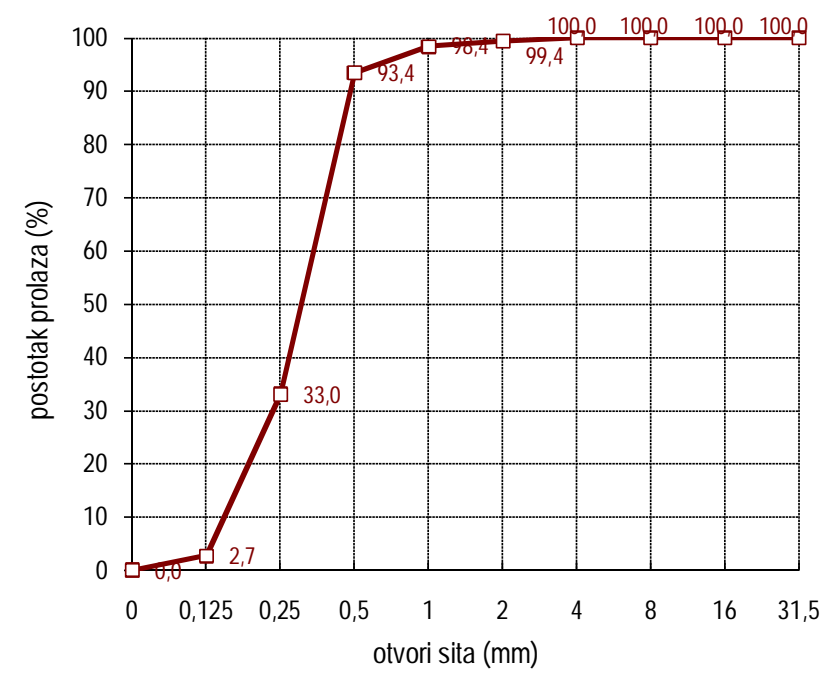

\section{Slika 1 - Granulometrijski sastav agregata $[10]$}

Alkalijski aktivator u mješavinama činili su 8-molarna otopina natrijevog hidroksida $(\mathrm{NaOH})$ i vodeno staklo $\left(\mathrm{Na}_{2} \mathrm{SiO}_{3}\right)$ u omjeru 1:2,5. S obzirom da je reakcija $\mathrm{NaOH}$ i vode prilikom izrade otopine $\mathrm{NaOH}$ egzotermna, otopina je spravljena dan prije nego što su spravljani mortovi s alkalijski aktiviranim vezivima, kako bi prilikom spravljanja mortova otopina bila sobne temperature. Maseni udjeli sastojaka za četiri različite mješavine navedeni su u tablici 3.

Tablica 3 - Maseni udjeli sastojaka mješavina morta

\begin{tabular}{|l|c|c|c|c|}
\hline \multirow{2}{*}{ Sastojci/Mješavina } & $\mathrm{M} 1$ & $\mathrm{M} 2$ & $\mathrm{M} 3$ & $\mathrm{M} 4$ \\
\cline { 2 - 5 } & $(\mathrm{kg})$ & $(\mathrm{kg})$ & $(\mathrm{kg})$ & $(\mathrm{kg})$ \\
\hline Pijesak & 1458,8 & 1319,7 & 1288,40 & \\
\hline Cement CEM I 52,5 N & 450,0 & - & - & - \\
\hline Zgura Sisak & - & 450,0 & 360,0 & 270,0 \\
\hline Silikatna prašina & - & - & 90,0 & 180,0 \\
\hline Aktivator & - & 393,75 & 393,75 & 393,75 \\
\hline Vodovezivni omjer (v/v) & 0,6 & 0,8 & 0,8 & 0,8 \\
\hline
\end{tabular}

Vodovezivni omjer u mješavinama M2 do M4 podrazumijeva omjer masa tekućeg dijela otopine $\mathrm{NaOH}$ i $\mathrm{Na}_{2} \mathrm{SiO}_{3}$ (masa tekućeg dijela otopine $\mathrm{NaOH}+$ masa vodenog stakla) i mase veziva (zgure iz Siska ili mješavina zgure iz Siska i silicijske prašine). 


\subsection{Izrada mješavina morta, svojstva svježeg morta i njega uzoraka}

Mješavine morta spravljene su u laboratorijskoj miješalici izgleda prema slici 2. Konzistencije mortova određene su na potresnom stoliću izgleda prema slici 3. Izmjerene konzistencije mortova prikazane su tablicom 4.

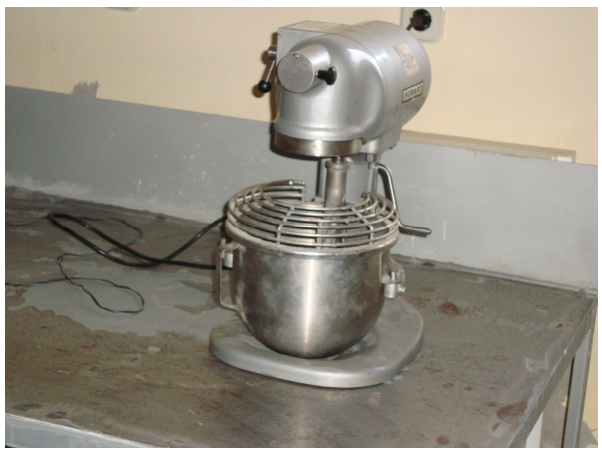

Slika 2 - Miješalica za spravljanje mješavina morta

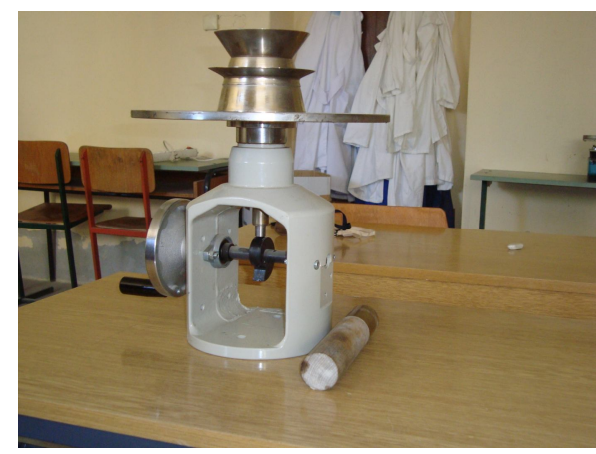

Slika 3 - Potresni stolić za određivanje konzistencije mortova

Tablica 4 - Konzistencija mješavina morta [10]

\begin{tabular}{|c|c|}
\hline Mješavina & Konzistencija (cm) \\
\hline M1 & 16 \\
\hline M2 & 16 \\
\hline M3 & 15 \\
\hline M4 & 14 \\
\hline
\end{tabular}

Od svake mješavine načinjeno je šest prizmica izmjera $4 / 4 / 16 \mathrm{~cm}$. Tri prizmice su bile namijenjene ispitivanju vlačnih i tlačnih čvrstoća nakon 2 dana starosti uzoraka, a tri su namijenjene ispitivanju vlačnih i tlačnih čvrstoća nakon 28 dana starosti uzoraka. Svježi mort zbijen je u kalupe na vibrostolu izgleda prema slici 4 . U starosti morta od 24h, uzorci prizmica izvađeni su iz kalupa i potopljeni u vodu do trenutka ispitivanja.

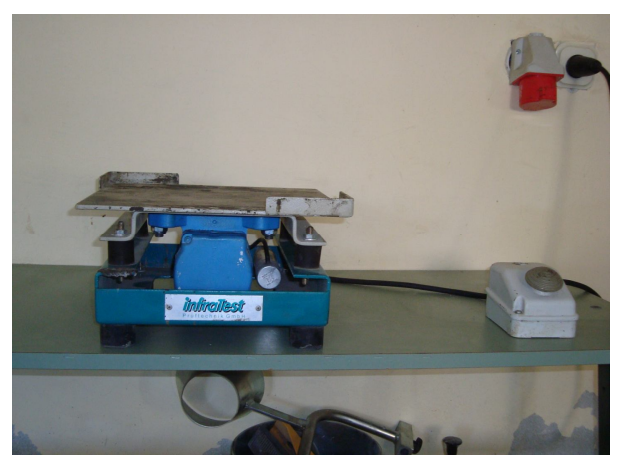

Slika 4 - Vibrostol za zbijanje svježeg morta

\subsection{Svojstva očvrsnulog morta}

\subsubsection{Postupci i rezultati ispitivanja}

Na uzorcima prizmica u starosti od 2 i 28 dana ispitane su vlačne čvrstoće morta savijanjem, a na nastalim polovicama prizmi tlačne čvrstoće morta. Ispitivanja vlačnih i tlačnih čvrstoća prikazana su slikama 7 i 8 . Rezultati ispitivanja vlačnih čvrstoća prikazani su slikama 9 i 10. Rezultati ispitivanja tlačnih čvrstoća na prizmama 
prikazani su tablicom 5 te slikama 11 i 12. Svaki od prikazanih rezultata ispitivanja je srednja vrijednost tri izmjerene vrijednosti.

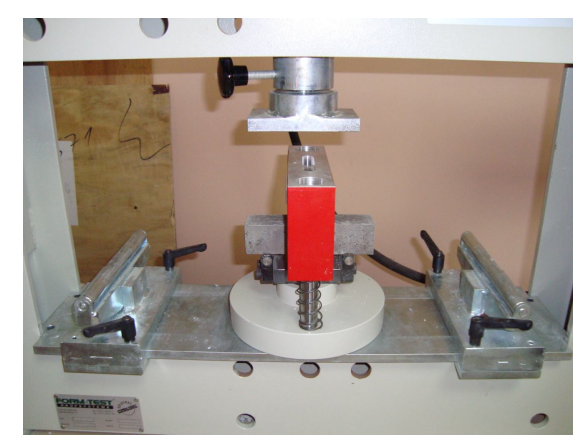

Slika 7 - Ispitivanje vlačne čvrstoće morta

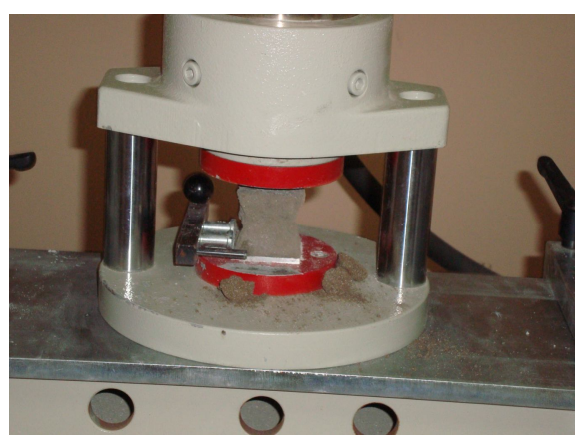

Slika 8 - Ispitivanje tlačne čvrstoće morta

\section{Tablica 5 - Vlačne i tlačne čvrstoće morta [10]}

\begin{tabular}{|c|c|c|c|c|}
\hline \multirow{2}{*}{ Mješavina } & \multicolumn{2}{|c|}{ Vlačna čvrstoća (MPa) } & \multicolumn{2}{c|}{ Tlačna čvrstoća (MPa) } \\
\cline { 2 - 5 } & nakon 2 dana & nakon 28 dana & nakon 2 dana & nakon 28 dana \\
\hline M1 & 3,3 & 4,1 & 15,5 & 20,9 \\
\hline M2 & 0,3 & 0,8 & 1,2 & 4,8 \\
\hline M3 & 0,6 & 0,7 & 4,6 & 4,7 \\
\hline M4 & 0,4 & 0,7 & 2,6 & 4,3 \\
\hline
\end{tabular}

$\square \mathrm{M} 1 \square \mathrm{M} 2 \square \mathrm{M} 3 \square \mathrm{M} 4$

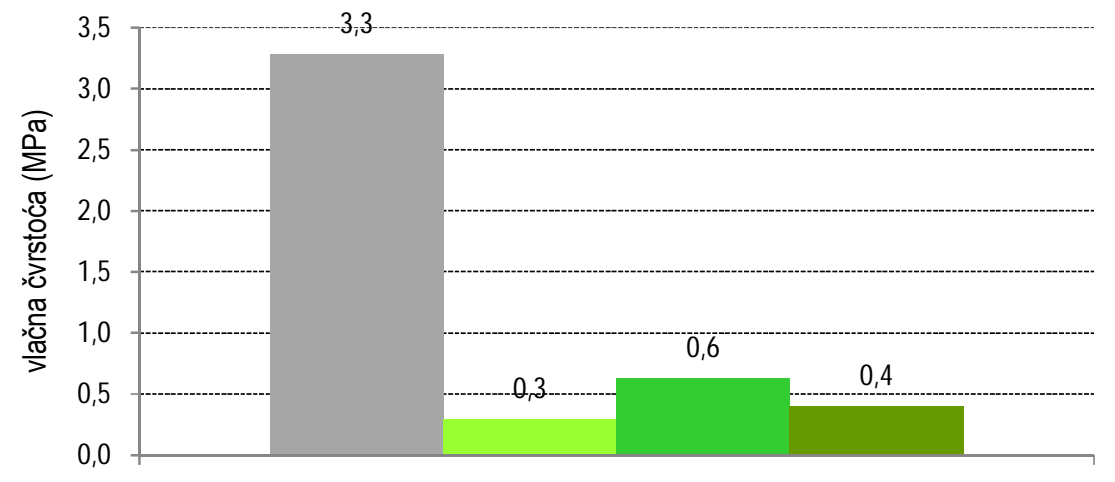

Slika 9 - Vlačne čvrstoće morta savijanjem nakon 2 dana starosti uzoraka 


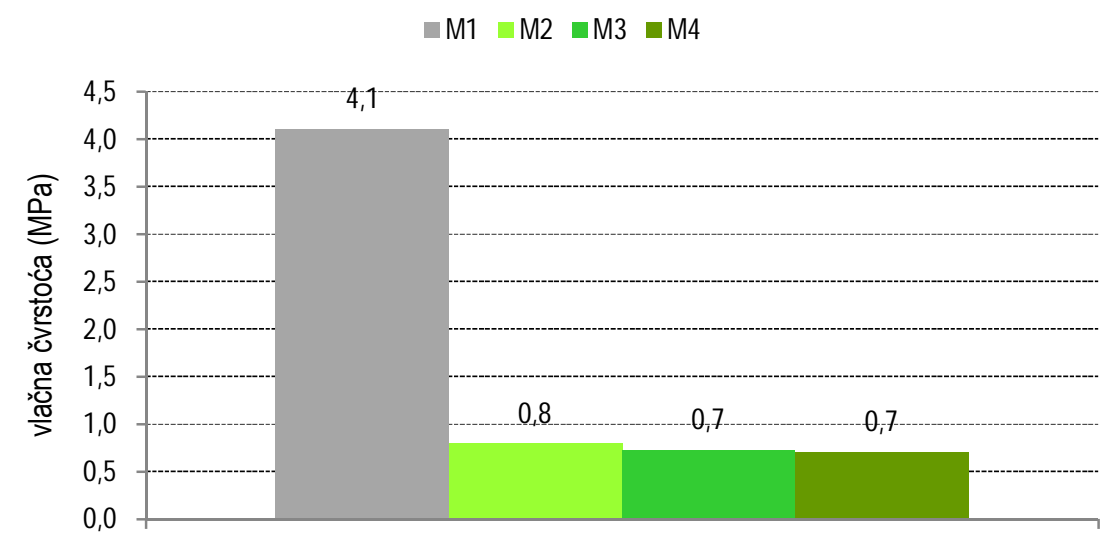

Slika 10 - Vlačne čvrstoće morta savijanjem nakon 28 dana starosti uzoraka

$\square \mathrm{M} 1 \backsim \mathrm{M} 2 \square \mathrm{M} 3 \square \mathrm{M} 4$

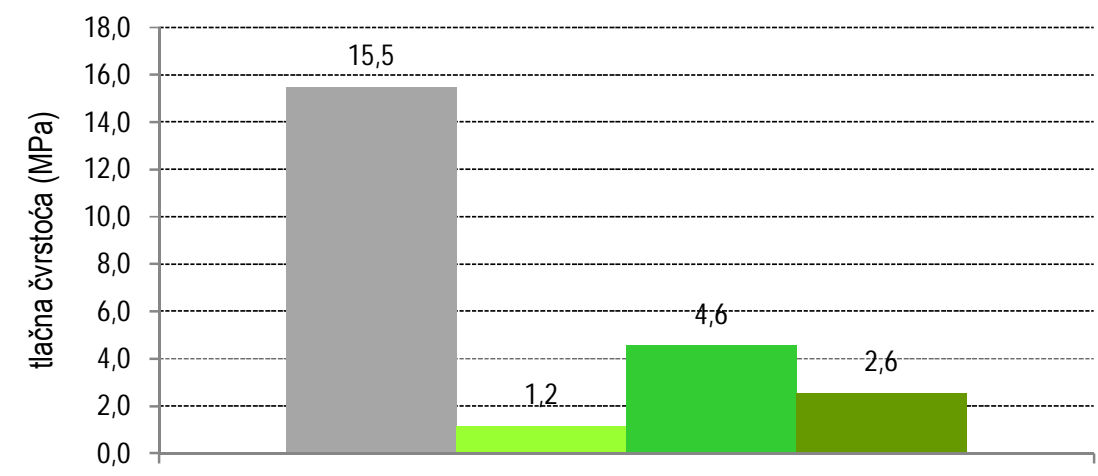

Slika 11 - Tlačne čvrstoće morta nakon 2 dana starosti uzoraka

$\square \mathrm{M} 1 \square \mathrm{M} 2 \square \mathrm{M} 3 \square \mathrm{M} 4$

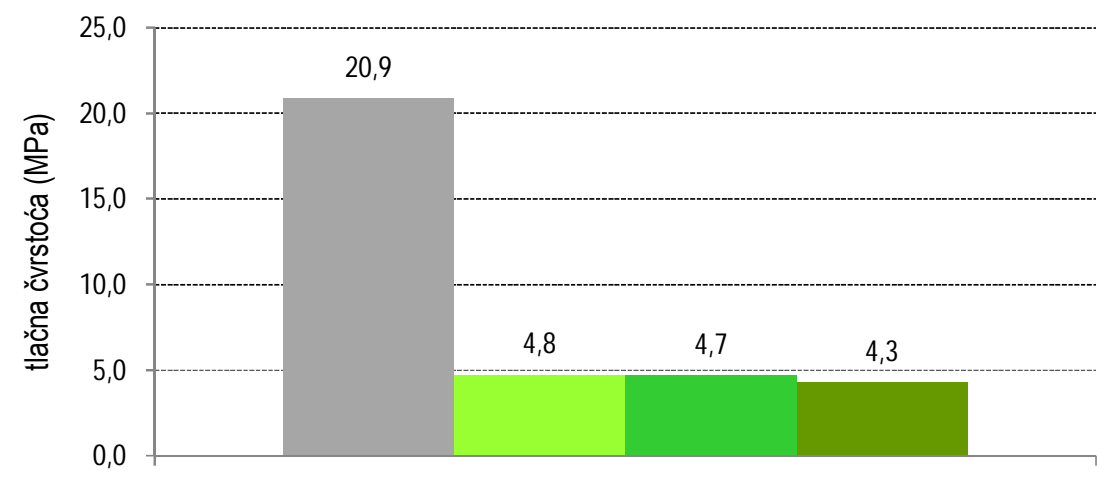

Slika 12 - Tlačne čvrstoće morta nakon 28 dana starosti uzoraka 


\section{Diskusija}

S obzirom na visoku klasu čvrstoće portlandskog cementa upotrijebljenog u mješavini $M 1$, znatne razlike u ostvarenim vlačnim i tlačnim čvrstoćama morta M1 i skupine mortova M2 do M4 su očekivane te ovdje nisu predmet rasprave. Usporedbom mehaničkih svojstava mortova M2 do M4 nakon 2 i 28 dana starosti uzoraka s mehaničkim svojstvima M1 pri istoj starosti uzoraka, vidljivo je da kontrolna mješavina (M1) ima brži prirast čvrstoće u odnosu na mješavine alkalijski aktiviranih mortova. Naime, nakon 2 dana starosti uzoraka, ostvarena vlačna čvrstoća uzoraka mješavine $\mathrm{M} 1$ iznosi $81 \%$, a vlačna čvrstoća uzoraka mješavina s alkalijski aktiviranom zgurom ili mješavinom zgure i silicijske prašine iznose 38\% (M2), 86\% (M3) i 56\% (M4) od ukupno ostvarene vlačne čvrstoće nakon 28 dana starosti. U pogledu tlačnih čvrstoća, nakon 2 dana starosti ostvareno je $74 \%$ od ukupno ostvarene tlačne čvrstoće kod mješavine M1, dok su mješavine M2 do M4 redom ostvarile $25 \%, 98 \%$ i $61 \%$ od ukupno ostvarene vrijednosti tlačne čvrstoće nakon 28 dana starosti. Zamjenom $20 \%$ zgure silicijskom prašinom (mješavina M3), ostvarene su veće vrijednosti vlačnih i tlačnih čvrtoća morta nakon 2 dana starosti uzoraka u odnosu na mort s isključivo alkalijski aktiviranom zgurom (mješavina M2). Zamjenom 40\% zgure silicijskom prašinom (mješavina M4), ostvarene su tek nešto veće vrijednosti mehaničkih svojstava morta nakon 2 dana starosti uzoraka u odnosu na mort s isključivo alkalijski aktiviranom zgurom (mješavina M2), te se tako zamjena $20 \%$ zgure silicijskom prašinom pokazala ovdje optimalnom. Zamjena zgure silicijskom prašinom nije imala utjecaja na tlačne i vlačne čvrstoće mortova nakon 28 dana starosti uzoraka.

\section{Zaključak}

S obzirom na činjenicu da se uspjela potaknuti vezivna aktivnost kod inače hidraulički neaktivnog materijala, autori zaključuju da je zguru moguće koristiti kao zamjenu za uobičajeno korišteno vezivo tj. cement, čime bi se pridonijelo zbrinjavanju otpada i očuvanju prirodnih resursa na području Republike Hrvatske. Ipak, prilično niske vrijednosti tlačnih i vlačnih čvrstoća kod mortova sa zgurom u usporedbi s istim vrijednostima kod portland cementnog morta, upućuju na potrebu za iznalaženjem nekog prikladnijeg načina njege svježeg morta s alkalijski aktiviranom zgurom u sastavu, kako bi mu se osigurale veće čvrstoće. Prema [2], veće vrijednosti mehaničkih svojstava (tlačne i vlačne čvrstoće) bilo bi moguće postići primjenom alkalijskog aktivatora jače koncentracije (veća molarnost otopine $\mathrm{NaOH}$ ) ili njegom uzoraka mortova pri povišenoj temperaturi. Međutim, neka istraživanja [11] pokazuju da povišena temperatura njege uzoraka može rezultirati čak i manjim čvrstoćama ako aktivator čine $\mathrm{NaOH}$ i vodeno staklo. Stoga se preporuča u daljnjim izučavanjima alkalijski aktivirane zgure istražiti utjecaj molarnosti otopine i povišene temperature njege uzoraka na čvrstoće mortova.

\section{Literatura}

[1] Palomo A.; Fernandez-Jimenez A.; Pastor J. Y.; Martin A.; Llorca, J. 2008: Alcali activated fly ash: Mechanical behaviour at high temperatures, 3rd International Symposium "Non-Traditional Cement \& Concrete", Brno University of Technology, Brno, Czech Republic, pp 525-535

[2] Pacheco-Torgal F.; Joao Castro-Gomes; Jalali S. 2008: Alkali-activated binders: A review. Part 2. About materials and binders manufacture, Construction and Building Materials, Volume 22, Issue 7, pp 1315-1322

[3] Buchwald A.; Schulz M. 2005: Alkali-activated binders by use of industrial by-products, Cement and Concrete Research, Volume 35, Issue 5, pp 968-973

[4] Pacheco-Torgal F.; Castro-Gomes J.; Jalali S. 2008: Alkali-activated binders: A review: Part 1. Historical background, terminology, reaction mechanisms and hydration products, Construction and Building Materials, Volume 22, Issue 7, pp 1305-1314

[5] Allahverdi A.; Najafi Kani E. 2008: Effects of chemical composition on basic engineering of natural pozzolanbased geopolymer cement, 3rd International Symposium "Non-Traditional Cement \& Concrete", Brno University of Technology, Brno, Czech Republic, pp 8-22 
[6] Krivenko P.; Kavalerova E. 2008: Performance of alkali-activated cements-perspective ways for carbon dioxide emissions reduction, 3rd International Symposium "Non-Traditional Cement \& Concrete", Brno University of Technology, Brno, Czech Republic, pp 389-399

[7] Wong H. S.; Abdul Razak H. 2005: Efficiency of calcined kaolin and silica fume as cement replacement material for strength performance, Cement and Concrete Research, Volume 35, Issue 4, pp 696-702

[8] Mazloom M.; Ramezanianpour A.A.; Brooks J.J. 2004: Effect of silica fume on mechanical properties og high-strength concrete, Cement \& Concrete Composites 26, Issue 4, pp 347-357

[9] Escalante-Garcia J.I.; Gorokhovsky A.V.; Mendoza G.; Fuentes, A.F. 2003: Effect of geothermal waste on strength and microstructure of alkali-activated slag cement mortars, Cement and Concrete Research, Volume 33, Issue 10, pp 1567-1574

[10] Ignjatić G. 2009: Utjecaj 20\% i 40\% dodane SiO2 prašine na proces hidratacije alkalijski aktivirane šljake završni rad, Osijek

[11] Fernández-Jiménez, A.; Palomo, J.G.; Puertas, F. 1999: Alkali-activated slag mortars: Mechanical strength behaviour Cement and Concrete Research, Volume 29, Issue 8, pp 1313-1321 